\title{
Review of A Fragmented Feminism: The Life and Letters of Anandibai Joshee by Meera Kosambi, Ram Ramaswamy, Madhavi Kolhatkar \& Aban Mukherji
}

ISBN 9780367463892

Published August 29, 2019, by Routledge India

280 Pages 33 B/W Illustrations

Reviewed by

Niranjana $G^{1} \&$ Bhuvaneswari ${ }^{2}$

${ }^{1}$ Research Scholar, VIT Chennai. Email: niranjjan87@gmail.com

${ }^{2}$ Assistant Professor, VIT Chennai

'A Fragmented Feminism THE LIFE AND LETTERS OF ANANDIBAI JOSHEE' is the seminal work on social history about the first woman doctor of India, Anandibai Gopal Joshee written by the sociologist Meera Kosambi and Edited by Ram Ramaswamy, Madhavi Kolhatkar and Aban Mukherji. It provides insight into the psychosocial impacts of culture on Indian women through the life of Dr. Anandibai Gopal Joshee, India's first women doctor.

The author collected the letters written by Anandibai, newspaper reports on her, her poems in Marathi and rare photographs of her to craft the biography of her life. This book resembles an epistolary style in its narrative quality accompanied by annotations and explanations by the author and Editors. Anandibai, who was graduated in western medicine at America, lived during the nineteenth century pre-independence India where access to basic education was a distant dream. This book stands as a witness to practices of child marriage, physical and emotional abusement on women. (Kosambi, 19)

'In childhood the mind is immature and the body undeveloped. And you know how I acted on these occasions. If I had left, you at that immature age, as you kept on suggesting, what would have happened? (And any number of girls have left their homes because of harassment from mothers-in-law and husbands). I did not do so because I was afraid that my ill-considered behaviour would tarnish my father's honour... And I requested you not to spare me, but to kill me. In out society, for centuries there has been no legal barrier between husband and wives; and if it exists, it works against women! Such being the vase, I had no recourse but to allow you to hit me with chairs and bear it with equanimity. A Hindu woman has not right to utter a word or to advise her husband. On the contrary she has right to allow her husband to do what he wishes and to keep quiet.'

The setting sprawls in a landscape where the women identified themselves as the Other of Men and fully dependent on Men for their existence. Despite the continuous harassment and

(c) AesthetixMS 2020. This Open Access article is published under a Creative Commons Attribution Non-Commercial 4.0 International License (http://creativecommons.org/licenses/by-nc/4.o/), which permits non-commercial re-use, distribution, and reproduction in any medium, provided the original work is properly cited. For citation use the DOI. For commercial re-use, please contact editor@rupkatha.com. 
physical abusement, Anandibai successfully achieved her dream of becoming a doctor. This book is a foreword to Indian feminist movement.

The first part of the book is concerned with early life of Anandibai, her American connection, and life at Calcutta and Serampore. The earlier works on Anandi Bai Joshee portrays her husband as a great reformer and camouflaged the hegemonical practices underplay, all the while defending the patriarchal politics in representing Anandibai in the world stage, but this book underscores the politics behind her representation and questions the legitimization process through which Anandibai is represented.

Pre-pubertal Marriages (child marriage) were predominant during that time consequently, infant mortality rate was also high which affected the gynaecological health of women. This book delineates the effect of child marriage and rigorous religious customs of Hindus Brahmanical society on women. Although, the access to basic education was a great deal for women those days except for the missionary schools, Anandibai finished her basic education in language and arts without proper schooling. The author and Editors greatly emphasize the emergence of the New World and its offerings to civilize the otherwise uncivilized third world countries of the world in Anandibai's correspondences with Mrs.Carpernter.

The second part of the book deals with her passage to America, stay at Carpenters, health issues and struggles at completing her medical graduation. Multiple offers from reputed universities is a great preamble for recognition of Indian women's talent and potential in the world stage. The growing and fragmented consciousness of Anandibai is evident in her letters as internal conflicts between Hindu and American way of life and from the disagreements with her husband. This book acts as an interface to the inner self of a woman who was contesting the equations of culture and education. (Kosambi, 173)

'I feel grieved at your habit of misinterpreting things. I did not at all mean to, even wish to, say that you treat me badly. I have only written about the excessive criticism Govindaro made of my having forgotten Marathi.'

The third part of the book talks about her brief voyage back to India and humiliations in the ship, which is the surviving proof for imperialistic monstrosities on Indian people. The author and editors substantiated Anandibai's letters with the reports from the acclaimed newspapers "The Mahratta” and "The Kesari” about her life.

Early marriage and pregnancy, fasting and poor eating habits crushed her dreams of serving the country and emancipate fellow women. She drearily performed the role of gender and religionimposed duties in the name of cultural codes. The culture, which was supposed to emancipate and legitimise, hampered her growth by naturalize and represent her as Indian women. There are accounts of life of Pandita Ramabai in the book, who was projected as a foil to Anandibai in the media during that time.

This book is the testimony for child marriage, child abusement, woman abusement, and subjugation in the name of religious practices and colonial violence. The entire nation was under subjugation, but women were dually subjugated under the colonial powers and Patriarchy. Anandibai's life is the metaphor for evils of Indian society on women. The influence of culture, patriarchal practices, and Indian code of conduct over Anandibai is clearly captured in her own words of correspondence.

The Editors tried to chronologically arrange the letters to better project the life of Anandibai but could not accomplish it. Even though, there are narrative interferences with letters and 
3 Review of A Fragmented Feminism: The Life and Letters of Anandibai Joshee by Meera

Kosambi, Ram Ramaswamy, Madhavi Kolhatkar \& Aban Mukherji

anecdotes from Anandibai's friends, the story is not lost in its entirety. The title, 'Fragmented Feminism' aptly denotes the fractured feminist consciousness in Anandibai, and the cultural factors obstructed her road to realisation. This revival of interest in re-publishing the life of Anandibai through her own words inspires all the Indian women seeking agency in social, domestic, economical, and political spheres.

\section{References:}

Kosambi, Meera. 'A Fragmented Feminism THE LIFE AND LETTERS OF ANANDIBAI JOSHEE'. Edited by Ram Ramaswamy, Madhavi Kolhatkar and Aban Mukherji. Routledge, 29 August 2019.

Butler, Judith, “Gender Trouble.” Routledge Classics, 2016.

Chakravarti, Uma. 'Gendering Caste: Through a Feminist Lens.' SAGE Publications Pvt. Ltd, ${ }_{5}$ October 2018.

John, E, Mary. 'Women’s studies in India: A Reader.' Penguin India 25 August 2008. 